\title{
Central infusion of leptin into well-fed and undernourished ewe lambs: effects on feed intake and serum concentrations of growth hormone and luteinizing hormone
}

\author{
C D Morrison, J A Daniel, B J Holmberg, J Djiane', N Raver², \\ A Gertler ${ }^{2}$ and D H Keisler \\ Department of Animal Sciences, University of Missouri, Columbia, Missouri 65211, USA \\ ${ }^{1}$ Laboratoire de Biologie Cellulaire, Institut National de la Recherche Agronomique, Centre de Recherche de Jouy, Jouy-en-Josas, Cedex, France \\ ${ }^{2}$ Institute of Biochemistry, Food Science and Nutrition, Faculty of Agricultural, Food and Environmental Quality Sciences, The Hebrew University of Jerusalem, \\ Rehovot, Israel \\ (Requests for offprints should be addressed to D H Keisler; Email: keislerd@missouri.edu)
}

\begin{abstract}
Leptin has been implicated in the regulation of feed intake, growth, and reproduction. The objective of this study was to determine if centrally administered leptin would affect feed intake and the secretion of growth hormone $(\mathrm{GH})$ and luteinizing hormone (LH) in ewe lambs. Eighteen ewe lambs were ovariectomized and fitted with intracerebroventricular (i.c.v.) cannulae. Lambs were randomly assigned to receive either a maintenance diet (fed), or a diet that provided $38 \%$ of maintenance requirements (diet-restricted) for 14 weeks. Subsequently, recombinant ovine leptin or vehicle was continuously infused, via i.c.v. cannulae, in a linearly increasing dose for 8 days, reaching a maximum of $1.25 \mu \mathrm{g} / \mathrm{kg}$ per h. Feed intake was recorded on days -1 to 7 . Blood was collected via jugular cannulae every $10 \mathrm{~min}$ for $4 \mathrm{~h}$ on days $0,2,4,6$ and 8 for the determination of serum leptin, insulin, LH and GH. Leptin suppressed feed intake in fed lambs on days 4 to 7 $(P<0 \cdot 001)$, but had no effect on feed intake in dietrestricted lambs $(P>0 \cdot 25)$. Fed lambs had greater serum concentrations of leptin than diet-restricted lambs $(P=0 \cdot 007)$. Also, although not different on day 0 (pre-
\end{abstract}

treatment), on day 8 serum leptin concentrations were greater in leptin-treated lambs than in saline-treated lambs $(P=0.003)$. Insulin was lower in diet-restricted than in fed lambs $(P=0.003)$, but was not affected by leptin treatment $(P=0 \cdot 82)$. LH pulse frequencies were lower in dietrestricted lambs than in fed lambs $(P=0 \cdot 038)$, but were not affected by leptin treatment $(P=0 \cdot 85)$. Mean serum $\mathrm{GH}$ was greater in diet-restricted than in fed lambs $(P<0 \cdot 01)$. In diet-restricted lambs treated with leptin or saline, mean $\mathrm{GH}$ did not differ on day 0 , but increased in response to leptin treatment $(P<0 \cdot 006)$. Treatment of fed lambs with leptin did not affect serum GH $(P>0 \cdot 32)$. From this work, we propose that leptin represents an important functional link between adipose stores and hypothalamic function in ruminants. We demonstrate that leptin concentrations change in response to reduced nutritional status, and that leptin has the ability to regulate multiple physiological processes in lambs, including both feed intake and secretion of $\mathrm{GH}$.

Journal of Endocrinology (2001) 168, 317-324

\section{Introduction}

The hypothalamus is critically involved in interactions among physiological systems, receiving and integrating nutritional cues from the body, and functioning to regulate nutritional status, reproduction, and growth through alterations in feed intake and neuroendocrine function. Of the circulating nutritional cues acting on the hypothalamus, leptin is currently receiving great attention (Friedman \& Halaas 1998, Houseknecht et al. 1998, Clarke \& Henry 1999, Schwartz et al. 2000). Because serum concentrations of leptin correlate highly with percent body fat in rodents and humans (Considine et al.
1996, Grinspoon et al. 1996, Ostlund et al. 1996, Ryan \& Elahi 1996, Weigle et al. 1997), it is proposed that leptin functions as a lipostatic signal, acting on the hypothalamus as a signal of body adipose mass. Much research is currently being done on the direct effects of leptin in rodents. The reports demonstrate that leptin is an important regulator of the hypothalamic, neuroendocrine, and endocrine processes regulating appetite (Campfield et al. 1995, Halaas et al. 1995, Pelleymounter et al. 1995), puberty (Ahima et al. 1997, Chehab et al. 1997, Cheung et al. 1997), and luteinizing hormone (LH) and growth hormone $(\mathrm{GH})$ secretion (Ahima et al. 1996, Barash et al. 1996, Carro et al. 1997, Kalra et al. 1998, Nagatani 
et al. 1998, Cocchi et al. 1999), especially in response to fasting.

In contrast, limited data have been generated regarding the administration of leptin to non-rodent species (Barb et al. 1998, Finn et al. 1998, Ramsey et al. 1998, Henry et al. 1999, Lado-Abeal et al. 1999, 2000, Tang-Christensen et al. 1999). Especially lacking are investigations of the direct administration of leptin to nutrient-restricted animals, with few data existing for species other than rodents and short-term fasted primates (Finn et al. 1998, Lado-Abeal et al. 1999, 2000). These observations emphasize a deficiency in our understanding of leptin physiology, especially when considering the unique differences that exist between rodents and other species.

Ruminants represent a physiological system distinct from rodents, but one critically important agriculturally and experimentally. The existence of the rumen and the relatively larger body fat reserves within the ruminant serve as a buffer to rapid physiological changes that accompany acute caloric and protein restriction in monogastrics. Also of note is the dichotomy of neuroendocrine responses to the undernourished condition exhibited by ruminants and rodents, especially in the somatotrophic axis. Because nutrient-restricted rodents exhibit reduced GH concentrations (Tannenbaum et al. 1979, Sisk \& Bronson 1986, Bronson \& Heideman 1990, Bruno et al. 1990) whereas nutrient-restricted ruminants and most other livestock and primates exhibit increased GH concentrations (Vandergrift et al. 1985, Phillips 1986, Gluckman et al. 1987, Foster et al. 1989, Thissen et al. 1994), it may be premature to extrapolate the somatotrophic responses of rodents to nutrient restriction in order to predict responses within ruminants or other species.

Although data exist pertaining to the existence of leptin and its receptor in livestock species (Dyer et al. 1997a,b, Ramsay et al. 1998), few reports describe the direct administration of leptin to livestock (Barb et al. 1998, Henry et al. 1999). Unfortunately, neither of the latter two groups addressed the response of undernourished animals to leptin. Thus information concerning the ability of leptin to alleviate nutritionally induced changes in the gonadotrophic and somatotrophic axes in undernourished livestock is currently lacking. To examine the role of leptin in the regulation of feed intake and the secretion of $\mathrm{LH}$ and $\mathrm{GH}$, we infused leptin intracerebroventricularly (i.c.v.) for 8 days into both well-fed and undernourished ewe lambs. We hypothesized that continuous i.c.v. infusion of leptin would alleviate the suppressed gonadotrophic axis and the stimulated somatotrophic axis observed in undernourished lambs.

\section{Materials and Methods}

\section{Animals and treatment groups}

All animals and procedures used in this experiment were approved by the University of Missouri-Columbia Animal
Care and Use Committee. Eighteen ovariectomized yearling crossbred ewe lambs averaging $40 \pm 1 \mathrm{~kg}$ in weight were individually housed indoors under a photoperiod of $10 \mathrm{~h}$ light : $14 \mathrm{~h}$ darkness. Lambs were ovariectomized at 27 weeks of age to avoid complications resulting from gonadal steroid feedback and estrous cyclicity. During a 14-day acclimation period, lambs were fitted with two lateral cerebroventricular cannulae (McShane et al. 1992) and immediately thereafter randomly assigned to receive one of two diets. Nine lambs received a maintenance diet $(800 \mathrm{~g} /$ day) of a mixed ration (fed), and nine lambs received 38\% of the maintenance diet $(300 \mathrm{~g} /$ day; dietrestricted). Lambs were fed once daily in the afternoon, and had free access to water.

\section{Infusion procedure}

After a 14-week dietary adaptation period, fed and dietrestricted lambs were randomly assigned to receive i.c.v. infusions of either leptin ( $n=5$ lambs per group; leptin diet-restricted and leptin fed) or saline $(n=4$ lambs per group; saline diet-restricted and saline fed) over an 8-day infusion period. Recombinant ovine leptin was produced and purified as described by Gertler et al. (1998). Lyophilized leptin was initially dissolved in distilled, deionized water to facilitate solubilization, and then diluted in sterile, physiological saline for infusion. Delivery of the infusate was controlled by computer, which incrementally increased the volume delivered each hour. This procedure allowed for a constant, linearly increasing delivery of the infusate (Rozell \& Keisler 1990). The infusion was designed so that a maximum dose of $1 \cdot 25 \mu \mathrm{g} / \mathrm{kg}$ per $\mathrm{h}$ of recombinant ovine leptin would be reached on day 8 of the infusion, with half the maximum dose being delivered on day 4. The saline-treated lambs received volumes identical to that infused into the leptin lambs (range $0-2 \mathrm{ml} / \mathrm{h}$ ). This infusion procedure was utilized because it allowed an investigation of the effects of continuous, long-term exposure to leptin, in addition to the response to a continuum of doses.

\section{Data collection}

Lambs were allowed access to feed for $1 \mathrm{~h}$ each afternoon. Weight of feed remaining after $1 \mathrm{~h}$ was subtracted from the total daily ration to estimate daily feed intake. Before the initiation of infusions, lambs were fitted with indwelling jugular cannulae. On days 0, 2, 4, 6 and 8 blood samples were collected every $10 \mathrm{~min}$ for $4 \mathrm{~h}$. Samples were collected in the afternoon, with feed offered approximately $1 \mathrm{~h}$ after the last sample. Samples were allowed to clot overnight at $4{ }^{\circ} \mathrm{C}$, and serum was harvested and stored at $-20^{\circ} \mathrm{C}$ until required for assay. Serum LH and GH concentrations were determined via double antibody radioimmunoassay procedures (Rozell \& Keisler 1990, Powell \& Keisler 1995). Briefly, serum concentrations of 
LH and GH were separately determined in duplicate $200-\mu 1$ serum samples. LH was determined with the RAoLH TEA No. 35 heterologous ovine antiserum (Adams et al. 1975) and reagents provided by the National Institute of Diabetes and Digestive and Kidney Diseases National Hormone and Pituitary Program (NIDDKNHPP; courtesy of Dr A F Parlow). GH was determined using the AFPC0123080 anti-ovine growth hormone primary antisera and other reagents also provided by the NIDDK-NHPP. The GH and LH intra- and interassay coefficients of variation were 4 and $6 \%$ for GH and 5 and $15 \%$ for LH respectively. Serum concentrations of leptin were determined in samples collected on day 0 and day 8 via double-antibody radioimmunoassay procedures (Delavaud et al. 2000). Briefly, serum concentrations of leptin were assayed in duplicate $200-\mu \mathrm{l}$ samples using a rabbit anti-ovine leptin primary antibody, iodinated ovine leptin (Gertler et al. 1998) and sheep anti-rabbit secondary antibody. The leptin intra- and interassay coefficients of variation were 4 and $11 \%$ respectively. Serum concentrations of insulin were determined using a commercially available insulin kit (Diagnostic Products Corporation, Los Angeles, CA, USA). For each lamb on days 0, 4, and 8, serum concentrations of insulin were determined in hourly pools of the individual 10-min samples. Samples were assayed in duplicate in a single assay, with a coefficient of variation of $2 \%$.

\section{Statistical analysis}

Mean concentrations of $\mathrm{LH}$ and $\mathrm{GH}$ and pulse frequencies and amplitudes of $\mathrm{LH}$ and GH were determined for each animal within each day using the CLUSTER pulse analysis program (Veldhuis \& Johnson 1986). Mean concentrations of leptin, representing an average of the 25 samples collected during the 4-h sampling interval on days 0 and 8 , were determined for each animal and analyzed using the general linear model SAS (1996) procedure. Effects in the model were treatment (infusion of leptin compared with saline), nutrition (fed compared with diet-restricted), and the treatment $\times$ nutrition interaction. Daily feed intake, mean serum concentrations of insulin, $\mathrm{LH}$ and $\mathrm{GH}$, and $\mathrm{LH}$ and $\mathrm{GH}$ pulse frequencies and amplitudes (per 4-h sampling interval) were analyzed as repeated measures using the Mixed Model Procedures of SAS (SAS 1996, Littell et al. 1996). Multiple covariance structures were tested, and the model-fitting statistics were compared to determine the best fitting model. Effects within the model were treatment (leptin compared with saline), nutrition (fed compared with diet-restricted), day of infusion and all possible interactions. Mean separation procedures were conducted using the LSMEANS statement with the PDIFF option in both GLM and MIXED, and thus represent least significant differences tests for all pair-wise comparisons within the significant main effect

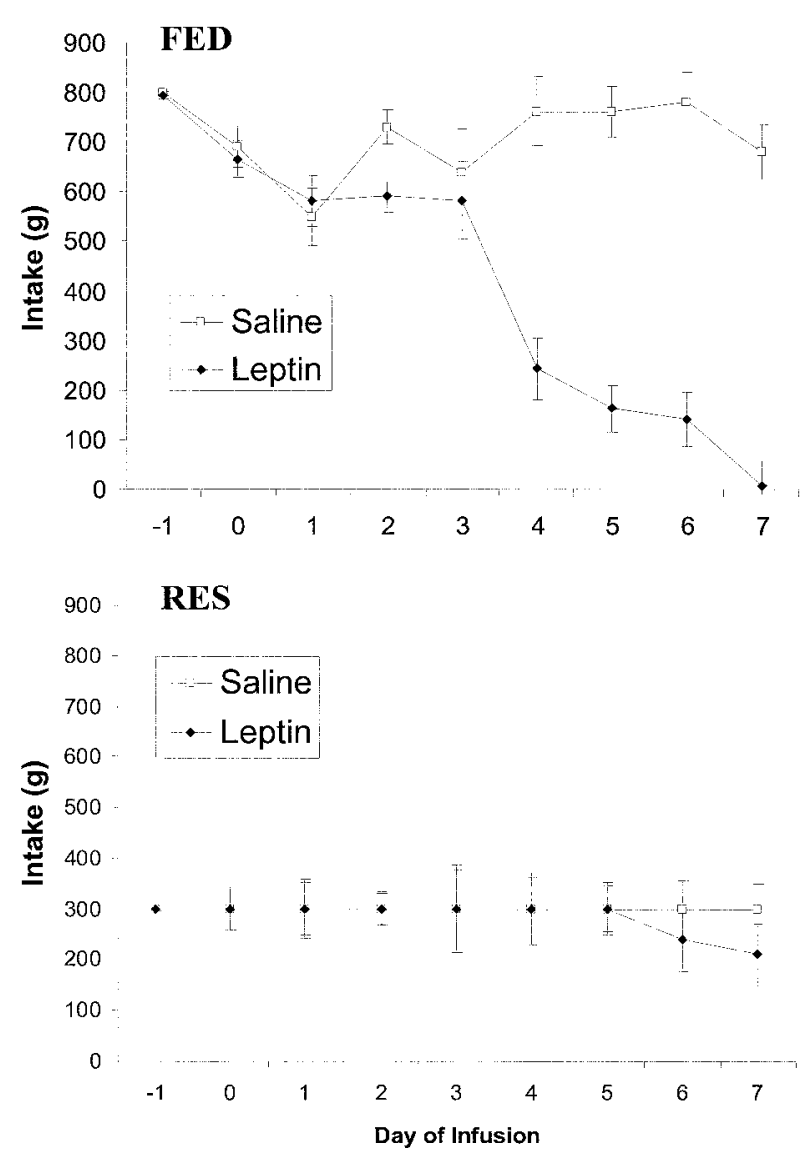

Figure 1 Feed intake in fed (FED) and diet-restricted (RES) lambs treated with leptin or saline. Leptin decreased feed intake in fed lambs on days 4 to 7 compared with that in saline-infused controls $(P<0 \cdot 001)$, but had no effect on feed intake in diet-restricted lambs $(P>0 \cdot 25)$.

or interaction. Data are presented as least squares means \pm s.E.M.

\section{Results}

\section{Feed intake}

At the initiation of the infusions, fed lambs weighed $43 \pm 2 \mathrm{~kg}$ and diet-restricted lambs weighed $23 \pm 1 \mathrm{~kg}$. Because fed and diet-restricted lambs were offered differing amounts of feed, the effect of nutritional status on feed intake was experimentally imposed and therefore only differences within nutritional groups were evaluated. Feed intake in fed lambs (Fig. 1) differed significantly with respect to treatment and day (treatment $\times$ day, $P=0 \cdot 001$ ). On day 0 , no difference in feed intake existed between leptin- and saline-infused fed lambs $(P=0.66)-a$ trend that continued until day 3 . However, by day 4 , leptininfused fed lambs ate less than saline-infused fed lambs, 

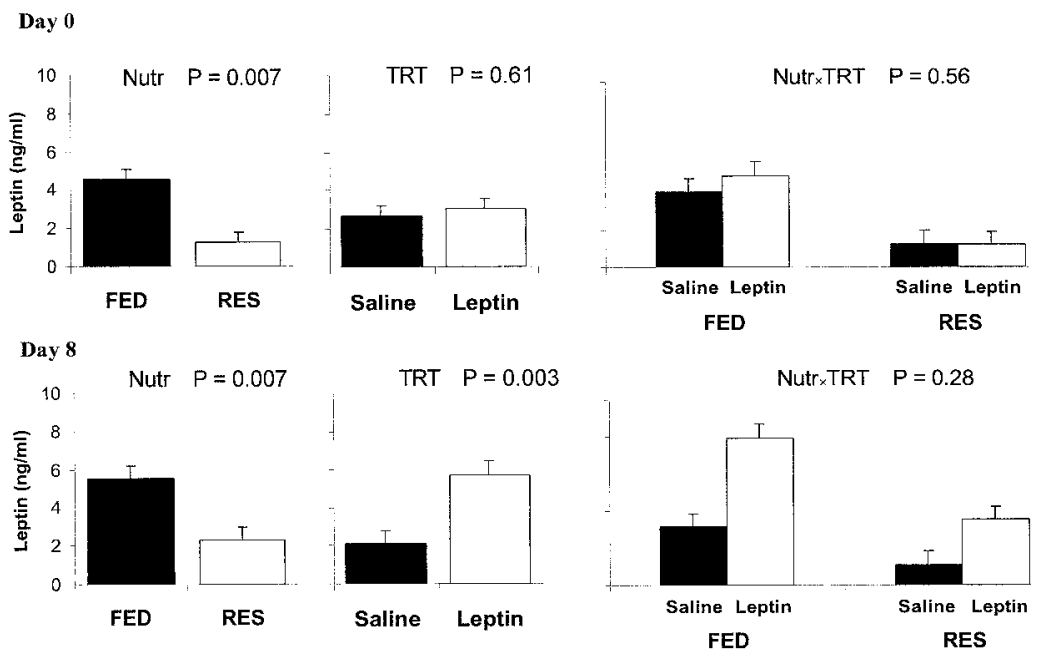

Figure 2 Serum concentrations of leptin on day 0 (pretreatment) and day 8 in fed (FED) and diet-restricted (RES) lambs treated with leptin or saline. Serum leptin was influenced by nutritional status on day 0 , fed lambs having greater leptin concentrations than diet-restricted lambs $(P=0.007)$. On day 8 , serum concentrations of leptin were influenced by nutritional status $(P=0.007)$ and leptin treatment $(P=0.003)$, concentrations of leptin being greater in leptin-treated than in saline-treated lambs. Nutr, nutritional status; TRT, treatment.
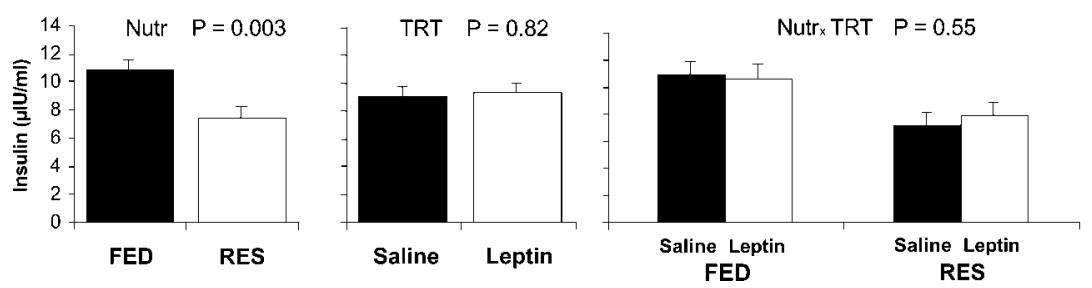

Figure 3 Serum concentrations of insulin in fed (FED) and diet-restricted (RES) lambs over the entire experiment. Fed lambs had greater mean concentrations of insulin than diet-restricted lambs throughout the study $(P=0.003)$, indicative of the difference in nutritional status. Leptin treatment did not affect serum concentrations of insulin at any time measured $(P=0 \cdot 82)$, despite the increase in serum leptin. Nutr, nutritional status; TRT, treatment.

with feed intake continuing to decline to day $7(P<0 \cdot 001)$. In contrast to the feed intake in fed lambs, that in diet-restricted lambs did not differ with respect to treatment or day (Fig. 1; $P>0 \cdot 25$ ).

\section{Serum leptin}

Nutritional status had a significant effect on mean serum concentrations of leptin on day 0 , with fed lambs having greater concentrations of leptin than diet-restricted lambs $(P=0 \cdot 007$; Fig. 2$)$. On day 8 , serum concentrations of leptin differed with respect to nutritional status $(P=0 \cdot 007$; Fig. 2) and leptin treatment $(P=0 \cdot 003)$. Serum concentrations of leptin were greater in fed than in diet-restricted lambs, but were also greater in leptin-treated lambs than in saline-treated lambs.
Insulin

Serum concentrations of insulin differed with respect to nutritional status, fed lambs having greater mean concentrations of insulin than diet-restricted lambs throughout the entire experiment $(P=0 \cdot 003$; Fig. 3). Treatment of lambs with leptin and the subsequent increase in serum leptin concentrations had no effect on mean concentrations of insulin in fed or diet-restricted lambs $(P=0 \cdot 82)$.

\section{Luteinizing hormone and growth hormone}

Neither nutritional status nor infusion of leptin significantly influenced mean concentrations of LH $(P>0 \cdot 66)$. However, nutritional status affected LH pulse frequency, 

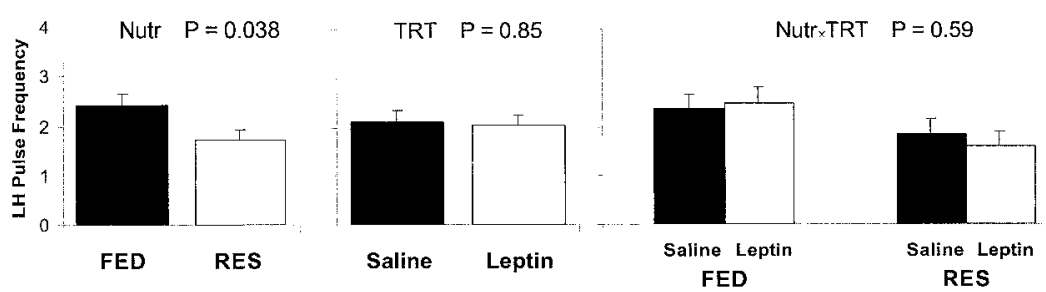

Figure $4 \mathrm{LH}$ pulse frequency (pulses per 4-h sampling interval) in fed (FED) and diet-restricted (RES) lambs. Diet-restricted lambs had fewer pulses per sampling interval than fed lambs throughout the study $(P=0 \cdot 038)$. Leptin treatment did not affect LH pulse frequency in fed or diet-restricted lambs on any day of measurement $(P=0 \cdot 85)$.

Nutr, nutritional status; TRT, treatment.

with diet-restricted lambs having fewer pulses per sampling interval than fed lambs over the entire experiment $(P=0 \cdot 038$; Fig. 4). Treatment of lambs with leptin did not affect LH pulse frequency in either the fed or dietrestricted lambs $(P=0 \cdot 85$; Fig. 4$)$, and neither nutritional status nor leptin treatment affected LH pulse amplitude $(P>0 \cdot 18)$.
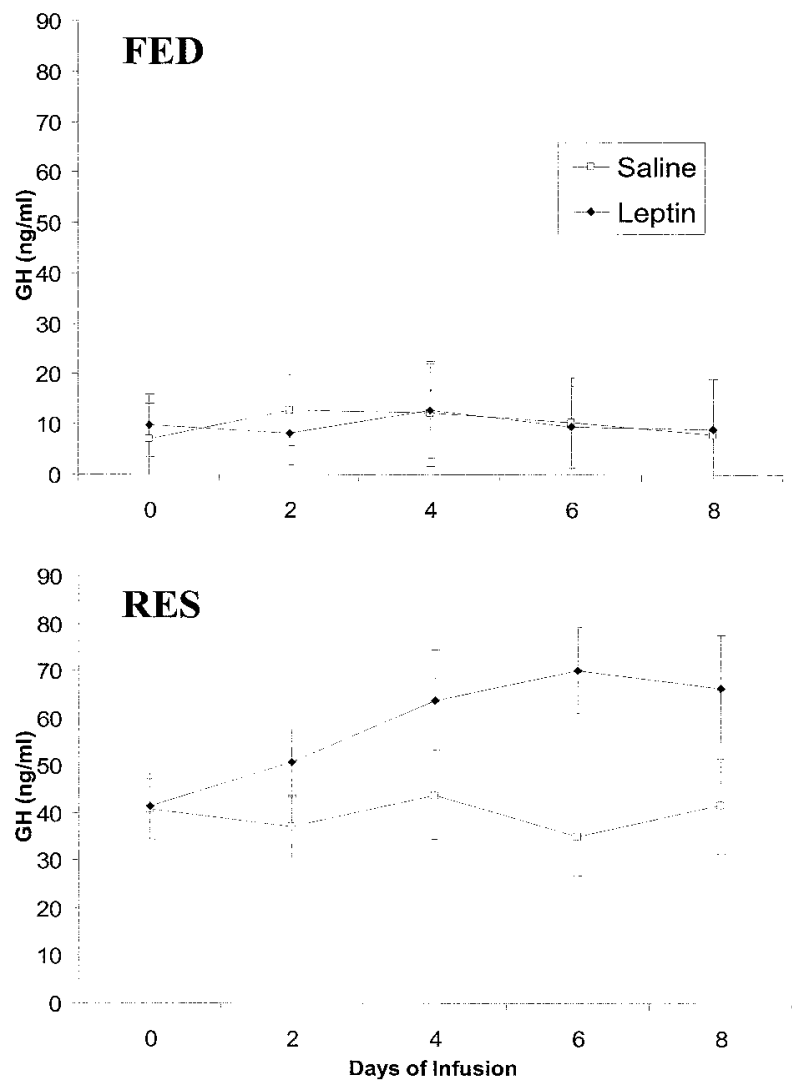

Figure 5 Mean serum concentrations of GH in fed (FED) and diet-restricted (RES) lambs treated with leptin or saline. GH was greater in diet-restricted than in fed lambs, regardless of treatment $(P<0 \cdot 01)$. Infusion of leptin had no effect on GH in fed lambs $(P>0 \cdot 32)$. Infusion of leptin increased serum concentrations of $\mathrm{GH}$ in diet-restricted lambs $(P<0 \cdot 006)$.
Mean concentrations of $\mathrm{GH}$ differed with respect to nutritional status, treatment, and day (treatment $\times$ nutrition $\times$ day, $P=0 \cdot 002$; Fig. 5). Mean GH was greater in diet-restricted than in fed lambs for all time periods, regardless of leptin treatment $(P<0 \cdot 01)$. Leptin had no effect on serum concentrations of $\mathrm{GH}$ in fed lambs $(P>0.32$; Fig. 5). However, leptin treatment increased serum concentrations of $\mathrm{GH}$ in diet-restricted lambs $P<0 \cdot 006)$. On day 0 (before leptin treatment), mean $\mathrm{GH}$ did not differ between leptin- and saline-infused dietrestricted lambs $(P=0 \cdot 9)$. In contrast, in diet-restricted lambs treated with leptin, GH increased from $41 \pm 7 \mathrm{ng} /$ $\mathrm{ml}$ on day 0 to a maximum of $70 \pm 9 \mathrm{ng} / \mathrm{ml}$ on day 6 $(P=0.006$; Fig. 5). Nutritional status altered GH pulse frequency and amplitude, with diet-restricted lambs having more pulses per sampling interval than fed lambs $(1.98 \pm 0.14$ compared with $1.36 \pm 0.14 ; P=0.026)$ and greater pulse amplitudes than fed lambs throughout the experiment $(81 \cdot 4 \pm 7 \cdot 5$ compared with $24 \pm 7 \cdot 7 \mathrm{ng} / \mathrm{ml}$; $P=0 \cdot 0001)$. Infusion of leptin had no effect on $\mathrm{GH}$ pulse frequency $(P>0.37)$, and did not significantly influence $\mathrm{GH}$ pulse amplitude, although leptin-treated dietrestricted lambs had numerically greater GH pulse amplitudes than saline-treated diet-restricted lambs on days 6 and 8 of the infusion $(113 \cdot 3 \pm 14 \cdot 4$ compared with $60 \cdot 4 \pm 12 \cdot 9$ on day $6 ; 103 \cdot 9 \pm 14 \cdot 4$ compared with $74 \cdot 4 \pm 12 \cdot 9 \mathrm{ng} / \mathrm{ml}$ on day 8 ; treatment $\times$ time $P=0 \cdot 10)$.

\section{Discussion}

If leptin serves as an endocrine signal linking peripheral adipose stores to regulatory centers within the hypothalamus, changes in nutritional status should be accompanied by changes in serum leptin concentrations. In the present study, serum concentrations of leptin were approximately three times lower in diet-restricted lambs than in fed lambs, supporting the findings of both Delavaud et al. (2000) and Blanche et al. (2000). This observation demonstrates that in the lamb, as in other species, serum leptin concentrations are responsive to changes in nutritional status, body fat mass, or both. It should be noted that serum 
leptin concentrations were greater in both fed and dietrestricted leptin-infused lambs than in saline-infused lambs on day 8 of the infusion. Although it is possible that i.c.v. infusion of leptin may influence peripheral secretion of leptin by yet unknown mechanisms, the more likely conclusion is that the i.c.v.-infused leptin simply diffused from the laterocerebroventricles into the peripheral circulation. Consequently, the observed effects of leptin treatment on feed intake and GH secretion may not be solely due to centrally mediated mechanisms.

Along with lower concentrations of leptin, dietrestricted lambs also had reduced serum concentrations of insulin, supporting the hypothesis that both leptin and insulin are circulating signals of nutritional status. Recent work has focused on interactions between leptin and insulin, proposing that insulin acts in an adipogenic/ leptogenic fashion, whereas leptin negatively regulates insulin secretion (Baskin et al. 1999, Loftus 1999, Kieffer \& Habener 2000, Schwartz et al. 2000). Although we did not expect i.c.v. delivery of leptin to alter peripheral concentrations of insulin, the opportunity to test the leptin-insulin interaction arose after the realization that serum leptin concentrations were indeed increased in response to i.c.v. infusion of leptin. In this study, the increase in serum concentrations of leptin had no effect on insulin concentrations. We conclude from these analyses that, although insulin may act to regulate leptin secretion (both were reduced in the diet-restricted lambs), moderate increases in serum concentrations of leptin may not affect serum concentrations of insulin in sheep. This observation illustrates potential differences that may exist in the insulin-leptin axis between ruminants and monogastric species, and also supports a regulation of feed intake and GH secretion by leptin that is independent of insulin.

Central infusion of leptin markedly suppressed feed intake in the fed, but not the diet-restricted lambs in this study. This strong effect illustrates that leptin does indeed regulate feed intake in ruminants, but the lack of effect on food intake in diet-restricted lambs raises questions as to the magnitude of control that leptin exerts over appetite in restricted lambs relative to other endogenous cues. As hypothalamic leptin receptor expression is increased in undernourished lambs (Dyer et al. 1997a), we anticipated an increase in leptin sensitivity in the diet-restricted lambs, but these lambs instead displayed a reduced sensitivity to the satiating effects of leptin. It should be noted that, because leptin was administered on a body-weight basis, the diet-restricted lambs received a mass of leptin that was approximately $50 \%$ of that delivered to the fed lambs. Thus it is possible that a greater dose of leptin would act to suppress intake in these diet-restricted lambs. Alternatively, other cues of nutritional status, such as insulin, might synergistically act with leptin to suppress appetite, as collateral mechanisms, mediated by metabolic or endocrine cues other than leptin, may coexist to ensure that the poorly nourished ruminant satisfies the need to eat.
In rodents (and, arguably, primates) previous studies have demonstrated a significant positive relationship between leptin and LH secretion. These studies primarily demonstrate that the suppression of LH secretion induced by nutrient restriction can be relieved by administration of leptin (Ahima et al. 1996, Finn et al. 1998, Kalra et al. 1998, Nagatani et al. 1998). In the present study, poor nutritional status significantly reduced $\mathrm{LH}$ pulse frequency, a classical reproductive response to undernutrition (Foster \& Olster 1985, Foster et al. 1989). However, infusion of leptin had no effect on mean LH or LH pulse frequency in either fed or diet-restricted lambs. Why leptin appears to stimulate $\mathrm{LH}$ in fasted rodents but not in our diet-restricted lambs is unknown. Because our lambs were in a chronic state of nutrient deprivation (and reduced LH secretion), leptin administration was anticipated to reverse this pre-existing condition. Contrastingly, most rodent work has examined the response to a shortterm fast, with leptin frequently being administered at or near the initiation of the fast (Ahima et al. 1996, Finn et al . 1998, Kalra et al. 1998, Nagatani et al. 1998). Thus in those studies leptin was not used to overcome a preexisting condition, but instead acted to prevent the induction of the condition. It remains to be determined if leptin will act similarly in acutely undernourished lambs or in lambs exposed to steroidal feedback.

In contrast to the unremarkable gonadotropic response, both nutritional status and infusion of leptin significantly altered serum concentrations of $\mathrm{GH}$. In diet-restricted lambs, the increased GH was consistent with the classic pattern observed in malnourished humans and livestock (Vandergrift et al. 1985, Phillips 1986, Gluckman et al. 1987, Foster et al. 1989, Thissen et al. 1994). We hypothesized that central infusion of leptin would act hypothalamically to communicate a high body fat condition, and thus GH would decrease in leptin-treated diet-restricted lambs to concentrations similar to those in fed lambs. Quite surprisingly, the opposite response was observed, in that i.c.v. infusion of leptin further increased the serum concentrations of $\mathrm{GH}$ in diet-restricted lambs, but did not alter GH in fed lambs. The mechanism for this nutrition-dependant stimulation is currently unknown. As GH promotes lipolysis (Hart et al. 1984, Dietz \& Schwartz 1991, Richelsen 1997), perhaps the increased GH is meant to mobilize the excess fat represented by high leptin concentrations. Also of interest is the possibility that the increase in GH in leptin-treated diet-restricted lambs is a response associated with compensatory or 'catch-up' growth (Boersma \& Wit 1997).

Previous work in rodents and pigs has demonstrated a stimulation of $\mathrm{GH}$ secretion after leptin administration (Carro et al. 1997, Barb et al. 1998, Tannenbaum et al. 1998, Vuagnat et al. 1998) and, in several studies, fasted animals were reported to display a more robust GH response than that in well fed animals (Carro et al. 1997, Vuagnat et al. 1998). We emphasize that the increase in 
GH in this study is clearly not a secondary effect of reduced intake or altered insulin secretion, because leptin infusion did not influence feed intake or insulin concentrations in the diet-restricted lambs. This work clearly shows that, in the ruminant, leptin can have direct effects on neuroendocrine function independent of its ability to modulate feed intake.

The results demonstrating a leptin-induced suppression of feed intake in fed lambs agree with the findings of others (Henry et al. 1999). However, because Henry and coworkers only used well-fed ewes, they were unable to demonstrate a change in either $\mathrm{LH}$ or $\mathrm{GH}$ in response to leptin infusion. Intriguingly, our present work also supports the dissociation of the neuroendocrine and appetiteregulatory functions of leptin in sheep previously described by Henry and coworkers (1999), although in the present study fed lambs displayed more sensitivity to appetiteregulatory effects, and diet-restricted lambs more sensitivity to neuroendocrine $(\mathrm{GH})$ regulatory effects.

From this work, we propose that leptin represents an important functional link between adipose stores and hypothalamic function in ruminants. We demonstrate that leptin concentrations change in response to reduced nutritional status, and that leptin has the ability to regulate multiple physiological processes in lambs, including both feed intake and neuroendocrine function.

\section{Acknowledgement}

This work was supported by a grant from the Missouri Agricultural Experimental Station Journal Series, Number 13042 .

\section{References}

Adams TE, Kinder JE, Chakraborty PK, Estergreen VL \& Reeves JJ 1975 Ewe luteal function influenced by pulsatile administration of synthetic LHRH/FSHRH. Endocrinology 97 1460-1467.

Ahima RS, Prabakaran D, Mantzoros C, Qu D, Lowell B, Maratos-Flier E \& Flier JS 1996 Role of leptin in the neuroendocrine response to fasting. Nature 382 250-252.

Ahima RS, Dushay J, Flier SN, Prabakaran D \& Flier JS 1997 Leptin accelerates the onset of puberty in normal female mice. Journal of Clinical Investigation 99 391-395.

Barash IA, Cheung CC, Weigle DS, Ren H, Kabigting EB, Kuijper JL, Clifton DK \& Steiner RA 1996 Leptin is a metabolic signal to the reproductive system. Endocrinology 137 3144-3147.

Barb CR, Yan X, Azain MJ, Kraeling RR, Rampacek GB \& Ramsay TG 1998 Recombinant porcine leptin reduces feed intake and stimulates growth hormone secretion in swine. Domestic Animal Endocrinology 15 77-86.

Baskin DG, Figlewicz Lattemann D, Seeley RJ, Woods SC, Porte D Jr, Schwartz MW 1999 Insulin and leptin dual adiposity signals to the brain for the regulation of food intake and body weight. Brain Research 848 114-123.

Blanche D, Tellam RL, Chagas LM, Blackberry MA, Vercoe PE, Martin GB 2000 Level of nutrition affects leptin concentrations in plasma and cerebrospinal fluid in sheep. Journal of Endocrinology 165 625-637.
Boersma B \& Wit JM 1997 Catch-up growth. Endocrine Reviews 18 646-661.

Bronson FH \& Heideman PD 1990 Short-term hormonal responses to food intake in peripubertal female rats. American Journal of Physiology 259 R25-R31.

Bruno JF, Olchovsky D, White JD, Leidy JW, Song J \& Berelowitz M 1990 Influence of food deprivation in the rat on hypothalamic expression of growth hormone-releasing factor and somatostatin. Endocrinology 127 2111-2116.

Campfield LA, Smith FJ, Guisez Y, Devos R \& Burn P 1995 Recombinant mouse $\mathrm{OB}$ protein: evidence for a peripheral signal linking adiposity and central neural networks. Science 269 546-549.

Carro E, Senaris R, Considine RV, Casanueva FF \& Dieguez C 1997 Regulation of in vivo growth hormone secretion by leptin. Endocrinology 138 2203-2206.

Chehab FF, Mounzih K, Lu R \& Lim ME 1997 Early onset of reproductive function in normal female mice treated with leptin. Science 275 88-90.

Cheung CC, Thornton JE, Kuijper JL, Weigle DS, Clifton DK \& Steiner RA 1997 Leptin is a metabolic gate for the onset of puberty in the female rat. Endocrinology 138 855-858.

Clarke IJ \& Henry BA 1999 Leptin and reproduction. Reviews of Reproduction 4 48-55.

Cocchi D, De Gennaro Colonna V, Bagnasco M, Bonacci D \& Muller EE 1999 Leptin regulates GH secretion in the rat by acting on GHRH and somatostatinergic functions. Journal of Endocrinology 162 95-99.

Considine RV, Sinha MK, Heiman ML, Kriauciunas A, Stephens TW, Nyce MR, Ohannesian JP, Marco CC, McKee LJ, Bauer TL \& Caro JF 1996 Serum immunoreactive-leptin concentrations in normal-weight and obese humans. New England Journal of Medicine 334 292-295.

Delavaud C, Bocquier F, Chilliard Y, Keisler DH, Gertler A \& Kann G 2000 Plasma leptin determination in ruminants: effect of nutritional status and body fatness on plasma leptin concentration assessed by a specific RIA in sheep. Journal of Endocrinology 165 $519-526$.

Dietz J \& Schwartz J 1991 Growth hormone alters lipolysis and hormone-sensitive lipase activity in 3T3-F442A adipocytes. Metabolism 40 800-806.

Dyer CJ, Simmons JM, Matteri RL \& Keisler DH 1997a Leptin receptor mRNA is expressed in ewe anterior pituitary and adipose tissues and is differentially expressed in hypothalamic regions of well-fed and feed-restricted ewes. Domestic Animal Endocrinology 14 $119-128$

Dyer CJ, Simmons JM, Matteri RL \& Keisler DH $1997 b$ cDNA cloning and tissue-specific gene expression of ovine leptin, NPY-Y1 receptor, and NPY-Y2 receptor. Domestic Animal Endocrinology 14 295-303

Finn PD, Cunningham MJ, Pau KY, Spies HG, Clifton DK \& Steiner RA 1998 The stimulatory effect of leptin on the neuroendocrine reproductive axis of the monkey. Endocrinology 139 4652-4662.

Foster DL \& Olster DH 1985 Effect of restricted nutrition on puberty in the lamb: patterns of tonic luteinizing hormone (LH) secretion and competency of the LH surge system. Endocrinology 116 375-381.

Foster DL, Ebling FJ, Micka AF, Vannerson LA, Bucholtz DC, Wood RI, Suttie JM \& Fenner DE 1989 Metabolic interfaces between growth and reproduction: I. Nutritional modulation of gonadotropin, prolactin and growth hormone secretion in the growth-limited female lamb. Endocrinology 125 342-350.

Friedman JM \& Halaas JL 1998 Leptin and the regulation of body weight in mammals. Nature $395763-770$.

Gertler A, Simmons J \& Keisler DH 1998 Large-scale preparation of biologically active recombinant ovine obese protein (leptin). FEBS Letters 422 137-140. 
Gluckman PD, Breier BH \& Davis SR 1987 Physiology of the somatotropic axis with particular reference to the ruminant. Journal of Dairy Science 70 442-466.

Grinspoon S, Gulick T, Askari H, Landt M, Lee K, Anderson E, Ma Z, Vignati L, Bowsher R, Herzog D \& Klibanski A 1996 Serum leptin levels in women with anorexia nervosa. Journal of Clinical Endocrinology and Metabolism 81 3861-3863.

Halaas JL, Gajiwala KS, Maffei M, Cohen SL, Chait BT, Rabinowitz D, Lallone RL, Burley SK \& Friedman JF 1995 Weight-reducing effects of the plasma protein encoded by the obese gene. Science $\mathbf{2 6 9}$ 543-546.

Hart IC, Chadwick PM, Boone TC, Langley KE, Ridman C \& Souza LM 1984 A comparison of the growth-promoting, lipolytic, diabetogenic and immunological properties of pituitary and recombinant-DNA-derived bovine growth hormone (somatotropin). Biochemical Journal 224 93-100.

Henry BA, Goding JW, Alexander WS, Tilbrook AJ, Canny BJ, Dunshea F, Rao A, Mansell A \& Clarke IJ 1999 Central administration of leptin to ovariectomized ewes inhibits food intake without affecting the secretion of hormones from the pituitary gland: evidence for a dissociation of effects on appetite and neuroendocrine function. Endocrinology 140 1175-1182.

Houseknecht KL, Baile CA, Matteri RL \& Spurlock ME 1998 The biology of leptin: a review. Journal of Animal Science 76 1405-1420.

Kalra SP, Xu B, Dube MG, Moldawer LL, Martin D \& Kalra PS 1998 Leptin and ciliary neurotropic factor (CNTF) inhibit fasting-induced suppression of luteinizing hormone release in rats: role of neuropeptide Y. Neuroscience Letters 240 45-49.

Kieffer TJ \& Habener JF 2000 The adipoinsular axis: effects of leptin on pancreatic beta-cells. Americal Journal of Physiology 278 E1-E14.

Lado-Abeal J, Lukyanenko YO, Swamy S, Hermida RC, Hutson JC \& Norman RL 1999 Short-term leptin infusion does not affect circulating levels of $\mathrm{LH}$, testosterone or cortisol in food-restricted pubertal male rhesus macaques. Clinical Endocrinology 51 41-51.

Lado-Abeal J, Hickox JR, Cheung TL, Veldhuis JD, Hardy DM \& Norman RL 2000 Neuroendocrine consequences of fasting in adult male macaques: effects of recombinant rhesus macaque leptin infusion. Neuroendocrinology 71 196-208.

Littell RC, Milliken GA, Stroup WW, \& Wolfinger RD 1996 SAS System for Mixed Models, Cary, NC: SAS Institute Inc., p 633.

Loftus TM 1999 An adipocyte-central nervous system regulatory loop in the control of adipose homeostasis. Seminars in Cell and Developmental Biology 10 11-18.

McShane TM, May T, Miner JL \& Keisler DH 1992 Central actions of neuropeptide-Y may provide a neuromodulatory link between nutrition and reproduction. Biology of Reproduction 46 1151-1157.

Nagatani S, Guthikonda P, Thompson RC, Tsukamura H, Maeda KI \& Foster DL 1998 Evidence for GnRH regulation by leptin: leptin administration prevents reduced pulsatile $\mathrm{LH}$ secretion during fasting. Neuroendocrinology 67 370-376.

Ostlund RE Jr, Yang JW, Klein S \& Gingerich R 1996 Relation between plasma leptin concentration and body fat, gender, diet, age, and metabolic covariates. Journal of Clinical Endocrinology and Metabolism 81 3909-3913.

Pelleymounter MA, Cullen MJ, Baker MB, Hecht R, Winters D, Boone T \& Collins F 1995 Effects of the obese gene product on body weight regulation in ob/ob mice. Science $269540-543$.

Phillips LS 1986 Nutrition, somatomedins, and the brain. Metabolism 35 78-87.

Powell MT \& Keisler DH 1995 A potential strategy for decreasing milk production in the ewe at weaning using a growth hormone release blocker. Journal of Animal Science 73 1901-1905.
Ramsay TG, Yan X \& Morrison C 1998 The obesity gene in swine: sequence and expression of porcine leptin. Journal of Animal Science 76 484-490.

Ramsey JJ, Kemnitz JW, Colman RJ, Cunningham D \& Swick AG 1998 Different central and peripheral responses to leptin in rhesus monkeys: brain transport may be limited. Journal of Clinical Endocrinology and Metabolism 83 3230-3235.

Richelsen B 1997 Action of growth hormone in adipose tissue. Hormone Research 48 105-110.

Rozell TG \& Keisler DH 1990 ffects of oestradiol on LH, FSH, and prolactin in ovariectomized ewes. Journal of Reproduction and Fertility 88 645-653.

Ryan AS \& Elahi D 1996 The effects of acute hyperglycemia and hyperinsulinemia on plasma leptin levels: its relationships with body fat, visceral adiposity, and age in women. Journal of Clinical Endocrinology and Metabolism 81 4433-4438.

SAS 1996 SAS/STAT Software: Changes and Enhancements Through Release 6.11. Cary, NC: SAS Institute Inc.

Schwartz MW, Woods SC, Porte D Jr, Seeley RJ \& Baskin DG 2000 Central nervous system control of food intake. Nature $\mathbf{4 0 4}$ 661-671.

Sisk CL \& Bronson FH 1986 Effects of food restriction and restoration on gonadotropin and growth hormone secretion in immature male rats. Biology of Reproduction 35 554-561.

Tang-Christensen M, Havel PJ, Jacobs RR, Larsen PJ \& Cameron JL 1999 Central administration of leptin inhibits food intake and activates the sympathetic nervous system in rhesus macaques. Journal of Clinical Endocrinology and Metabolism 84 711-717.

Tannenbaum GS, Rorstad O \& Brazeau P 1979 Effects of prolonged food deprivation on the ultradian growth hormone rhythm and immunoreactive somatostatin tissue levels in the rat. Endocrinology 104 1733-1738.

Tannenbaum GS, Gurd W \& Lapointe M 1998 Leptin is a potent stimulator of spontaneous pulsatile growth hormone $(\mathrm{GH})$ secretion and the GH response to GH-releasing hormone. Endocrinology 139 3871-3875.

Thissen J, Ketelslegers J \& Underwood LE 1994 Nutritional regulation of the insulin-like growth factors. Endocrine Reviews 15 80-101.

Vandergrift WL, Giraudo SQ, Campion DR \& Seerley RW 1985 Growth, carcass composition and selected hormone concentrations of restricted- and ad libitum-fed pigs. Journal of Animal Science $\mathbf{6 1}$ $1454-1459$

Veldhuis JD \& Johnson ML 1986 Cluster analysis: a simple, versatile, and robust algorithm for endocrine pulse detection. American Journal of Physiology 250 E486-E493.

Vuagnat BA, Pierroz DD, Lalaoui M, Englaro P, Pralong FP, Blum WF \& Aubert ML 1998 Evidence for a leptin-neuropeptide Y axis for the regulation of growth hormone secretion in the rat. Neuroendocrinology 67 291-300.

Weigle DS, Duell PB, Connor WE, Steiner RA, Soules MR \& Kuijper JL 1997 Effect of fasting, refeeding, and dietary fat restriction on plasma leptin levels. Journal of Clinical Endocrinology and Metabolism 82 561-565

Received in final form 7 September 2000 Accepted 29 September 2000 